\title{
THEOLOGICAL TERMS IN GERMAN: GENERAL OVERVIEW
}

\section{Veresh M. T.}

\section{INTRODUCTION}

The terminological systems of different languages for Special Purposes (LSP) in today's multicultural and globalized world are becoming increasingly important, since communication in the professional field requires thorough knowledge of not only the field itself, but also the means of its expressing. The term as a unit of a particular terminological system is a tool for professional communication. The term Christian-theological terminological system clearly defines the sphere of functioning - units that define concepts and phenomena in the field of theology as the doctrine of God and the Word of God based on Revelation.

The historical events of the 1990s, the legalization of the Catholic Church in the post-Soviet space contributed to the growth and spread of spirituality and made it possible to activate the church's public activities. At the same time, the process of introducing the discipline of "theology" at the state level was intensified.

\section{Theology as a science. Theological terms from the linguistic point of view. Languages for special purposes (LSP)}

In Christian world, the term theology is the doctrine of God based on Revelation, that is, the methodical attempt to understand and explain the Divine Revelation of truth ${ }^{1}$. This "Revelation is contained in the Holy Tradition and the Holy Scriptures of the Old and New Testaments and is entrusted to the Holy Church. The pinnacle of Divine Revelation is the incarnate of the Holy Spirit and Mary the Virgin, the Son of God - Jesus Christ, who in his words and deeds declared the love of God the Father"2. In our opinion, this aspect should be emphasized.

Theology is a scientific teaching in which "the Christian mind is confident and enlightened by the light of faith. It seeks by thought to understand what it believes in. The object of faith is the revealed

\footnotetext{
${ }^{1}$ Католическая Энциклопедия в 5-ти томах. - М. : Издательство Францисканцев, 2002. - T. 1. - С. 631.

${ }^{2}$ Катехизм Української Греко-Католицької Церкви : Христос - наша Пасха. - Львів : Свічадо, 2011. - С. 19.
} 
sacrament. Being aware of it, one realizes many consequences that follow from it" ${ }^{3}$. St. Thomas Aquinas thus covers the emergence of theology as a science: "It was necessary for man's salvation that there should be a knowledge revealed by God besides philosophical science built up by human reason. Firstly, indeed, because man is directed to God, as to an end that surpasses the grasp of his reason: "The eye hath not seen, O God, besides Thee, what things Thou hast prepared for them that wait for Thee" (Is. 66:4). But the end must first be known by men who are to direct their thoughts and actions to the end. Hence it was necessary for the salvation of man that certain truths which exceed human reason should be made known to him by divine revelation. Even as regards those truths about God which human reason could have discovered, it was necessary that man should be taught by a divine revelation; because the truth about God such as reason could discover, would only be known by a few, and that after a long time, and with the admixture of many errors. Whereas man's whole salvation, which is in God, depends upon the knowledge of this truth. Therefore, in order that the salvation of men might be brought about more fitly and more surely, it was necessary that they should be taught divine truths by divine revelation. It was therefore necessary that besides philosophical science built up by reason, there should be a sacred science learned through revelation"4.

The term "bohoslovya" in the Ukrainian language is synonymous with the terminological unit "heology", which is used in many languages, derived from the Greek words: $\lambda o ́ \gamma o \varsigma$ - word, concept, doctrine, and $\theta \varepsilon o ́ \varsigma$ God. $\theta \varepsilon o \lambda$ oyi $\alpha$ - the doctrine of God, theology (or as it can also be called in Ukrainian “богослов'я", i. e. "bohoslovya”) ${ }^{5}$. We should point out that the term "bohoslovya" derives from two words: Boh - God and slovo word, concept, doctrine. Thus, one can easily see that both terms point to the same reality. However, in certain circles there is a tendency to supplant the assimilated Church Slavonicism "bohoslovya" with the new Greek word "theology". Authors who use the term "bohoslovya" generally focus on Eastern Christian tradition, while those who use the term "theology" focus on Western Christian ones ${ }^{6}$.

\footnotetext{
${ }^{3}$ Стасяк С.-Я. Основи догматичного богослов'я / о. С.-Я. Стасяк, о. Р. Завіла. - Львів : Мiсіонер, 1997. - C.5

${ }^{4}$ St. Thomas Aquinas : [Електронний ресурс]. - Режим доступу : https://dhspriory.org/ thomas/summa/FP/FP001.html\#FPQ1OUTP1

${ }^{5}$ Греческо-русский словарь / [под ред. А.Д. Вейсмана]. - С. Петербург, 1899. - С. 601.

${ }^{6}$ Термінологічно-правописний порадник для богословів та редакторів богословських текстів. - Львів, вид. Інституту богословської термінології та перекладів Українського Католицького Університету, 2005. - С. 26.
} 
Early Christian apologists, namely Origen and Eusebius of Caesarea, first used the terminological unit "theology" . According to Origen, theology is the doctrine of God, in a special way about the Savior Jesus Christ. So, doing theology means acknowledging and praising God in Christ. <...> Theology also researches The Word of God, which the scholar (theologian) seeks to properly perceive and interpret, the faith and its effect on man and society (dogmatic and moral theology), Jesus Christ (Christology), man (theological anthropology) ${ }^{8}$.

When considering the terms of the Christian-theological terminological system, one should understand the concept of theology in the light of Catholic teaching, since it is interpreted differently. The Catechism of the Catholic Faith provides the following explanation: "The Fathers of the Church distinguish between theology (theologia) and economy (oikonomia). Theology refers to the mystery of God's inmost life within the Blessed Trinity and economy to all the works by which God reveals himself and communicates his life. Through the oikonomia the theologia is revealed to us; but conversely, the theologia illuminates the whole oikonomia. God's works reveal who he is in himself; the mystery of his inmost being enlightens our understanding of all his works" $"$.

With the emergence of the first universities in the $12^{\text {th }}$ century, including Bologna in 1088 and Paris in 1215, the sacred doctrine began to be called theology. Great credit goes to Pierre Abelard, a French philosopher and theologian who introduced the term "theology" in the title of his scholarly work "Theologia christiana" (Christian theology) ${ }^{10}$ [87, p. 632]. The term "theology" (Theologie) in German is a borrowing from the Greek language and dates from the $15^{\text {th }}$ century. It denotes the doctrine of God and His revelation, as well as the faith and essence of the church ${ }^{11}$.

Theology as a science has formed certain special disciplines in the course of historical development : ascetic (spiritual) theology, moral, fundamental, dogmatic and biblical theology, the theology of the Fathers of the Church, catechetic, homiletics, pastoral theology, liturgical and canon law ${ }^{12}$, each containing the relevant lexical units.

\footnotetext{
${ }^{7}$ Стасяк С.-Я. Основи догматичного богослов'я / о. С.-Я. Стасяк, о. Р. Завіла. - Львів : Місіонер, 1997. - С. 5.

8 Католическая Энциклопедия в 5-ти томах. - М. : Издательство Францисканцев, 2002. - T. 1. - C. 632.

${ }^{9}$ Catechism of the Catholic Church : [Електронний ресурс]. - Режим доступу : http://www.vatican.va/archive/ENG0015/_P17.HTM\#7X.

${ }^{10}$ Католическая Энциклопедия в 5-ти томах. - М. : Издательство Францисканцев, 2002. - T. 1. - C. 632.

${ }^{11}$ Duden, Etymologie : Herkunftswörterbuch der deutschen Sprache / [bearb. von G. Drosdowski]. - Mannheim, Leipzig, Wien, Zürich : Dudenverlag, 1997. - S. 743.

12 Обер о. Ж.-М. Моральне богослов'я / о. Жан-Марі Обер : [переклад 3 італ. о. д-ра М. І. Любачівського] : [2-ге вид, виправ.]. - Львів : Стрім, 1997. - С. 8-10.
} 
The concepts of "Languages for Special Purposes" (LSP) and "terminological system" in linguistics are interrelated. In order to clarify the relationship between these concepts, it is necessary to dwell on their definitions. According to L. Hoffmann, "LSP is the unity of all linguistic means used in the professionally limited communication field to ensure understanding between individuals in a particular field of activity"13. Languages for Special Purposes are also "means of optimal understanding of the subject area for professionals. They are characterized by a specific vocabulary and special rules for the choice, use and frequency of commonly used lexical and grammatical means. They do not exist as an independent form of realization in language, but is actualized in professional tests, which, in addition to the elements of the professional text, always contain elements of the common language” ${ }^{\text {"14 }}$. Languages for Special Purposes are "a set of all language means used in a professionally closed field of communication to ensure mutual understanding between people working in this field" 15 . "Languages for Special Purposes are means of cognition and conceptual definition of a specific reality of the profession, as well as a means of mutual understanding in the field, and thus takes into account the specific needs of communication within the profession" ${ }^{\text {" }}$.

Although there is no clear definition of the term "Languages for Special Purposes", the definitions of the term "LSP” given here make it possible to distinguish their main task, "which is to create accurate and economical meaningful tools for understanding the subject area or field of activity and serve mainly to meet the needs of professional communication" ${ }^{17}$. According to L. Hoffmann, professional communication is an externally or internally motivated or stimulated external and internal system of knowledge aimed at a chain of professional events that change the knowledge system of both one specialist and a group of specialists $^{18}$. Three concepts proposed by $\mathrm{T}$. Roelcke became the basis

${ }^{13}$ Hoffmann L. Kommunikationsmittel Fachsprache / L. Hoffmann // Forum für FachsprachenForschung. - [2., völlig neu bearb.]. - Tübingen : Narr, 1985. - B. 1. - S. 53.

${ }^{14}$ Schmidt S. J. Bedeutung und Begriff : Zur Fundierung einer sprachphilosophischen Semantik / S. J. Schmidt. - Braunschweig : Vieweg, 1969. - S. 17.

${ }^{15}$ Кияк Т. Р. Перекладознавство (німецько-український напрям) : [підруч. для студ. вищ. навч. закл.] / Т. Р. Кияк, А. М. Науменко, О. Д. Огуй. - К. : Київський нац. університет, 2009. - С. 55.

${ }^{16}$ Möhn D. Fachsprachen. Eine Einführung / D. Möhn, R. Pelka. - Tübingen, Max Niemeyer Verlag, 1984. - S. 26.

${ }^{17}$ Міщенко А. Л. Лінгвістика фахових мов та сучасна модель науково-технічного перекладу : монографія / А. Л. Міщенко. - Вінниця : Нова Книга, 2013. - С. 15.

18 Hoffmann L. Kohärenz und Kohäsion in wissenschaftssprachlichen Texten: ein Analysebeispiel // Fachsprachen. Ein internationales Handbuch zur Fachsprachenforschung und Terminologiewissenschaft. - Berlin - New York, 1998. - S. 614. 
for the study of Languages for Special Purposes. The first regards professional language as a system of linguistic signs. The second is aimed at professional text, as well as its contextual links that make professional communication possible. The third concept is related to the producer and the recipient of professional communication, thereby defining the cognitive properties of humans as the basis of linguistic research ${ }^{19}$.

Languages for Special Purposes can be represented in horizontal and vertical structuring. The horizontal division follows the principle of division according to the disciplines and specialist areas. Thus, there are LSP of consumption and trade, which include, in particular, beekeeping, shipping, book printing, hunting, animal husbandry and more. The next group consists of technical and LSP of applied sciences: computer science, telecommunications, electrical engineering and more. The third group of horizontal division is the LSP of the sciences, which include, in particular, law, physics, chemistry, biology, pharmacology, mathematics, pedagogy, linguistics, as well as theology. The fourth group includes the languages of institutions: politics, governance, etc. ${ }^{20}$ The vertical structuring does not adhere to the professional principle, but takes into account the level of abstractness. Thus, LSP differ in the level of the highest degree of abstraction (artificial symbols, formulas - basic theoretical sciences), the level of very high degree of abstractness (experimental sciences communication between scientists, technicians), high degree of abstraction (languages with a very high proportion of professional terminology and clear syntax - applied sciences), low abstractness (languages with a fairly high proportion of professional terminology and relatively unrelated syntax - the sphere of material production) and very low level of abstraction (languages with few professional terms and unrelated syntax the sphere of consumption and trade) ${ }^{21}$. Vertical structuring manifests itself, in particular, in the pragmatic conditions of the professional communication functioning and in linguistic selection (stylistics). Therefore, theology finds its place in the horizontal structuring and belongs to the LSP of science.

It should be noted that some LSP use specific language means that may be available in other LSP. Multiple subgroups can form larger classes with their common features. Yes, it is possible to distinguish a hierarchical system of LSP of theology and its sublanguages within the national

\footnotetext{
${ }^{19}$ Roelcke T. Fachsprachen / T. Roelcke - Berlin: Erich Schmidt Verlag, 2005. - S. 16-17.

${ }^{20}$ Ibid. - S. 37-38.

${ }^{21}$ Кияк Т. Р. Перекладознавство (німецько-український напрям) : [підруч. для студ. вищ. навч. закл.] / Т. Р. Кияк, А. М. Науменко, О. Д. Огуй. - К. : Київський нац. університет, 2009. - С. 57.
} 
language, in particular, the professional language of moral theology, pastoral theology, homiletics, liturgy, etc.

Languages for Special Purposes are primarily targeted at specialists in a particular field. Each profession has its own linguistic variability. E.S. Movchun, sharing the opinion of the representatives of the German School for the Study of LSP K. Baumann, L. Hoffmann, D. Möhn, R. Pelka, T. Roelcke and H.-R. Fluck, believes that "not only lexical but also syntactic features are inherent in every LSP". The use of certain syntactic constructions and a much smaller proportion of figurative terminological units distinguish Languages for Special Purposes from professional jargon (slang)",22. Professional communication "is closely related to human speech and is the subject of research in a number of related sciences and subdisciplines of general linguistics, including pragmatics, which explores the use of language signs, grammatical structures and stylistic patterns adequate in the professional text to achieve the communicative purpose as well as the terminology that is associated with the professional language in terms of applied terminology and terminological activity, in particular, the formation of modern terminological systems, the problems of term formation, normalization, standardization, harmonization and up-to-date maintenance of industry terminologies at national and international levels"23.

Languages for Special Purposes exist at the level of vocabulary, syntax and text. All vocabulary of the professional text is divided into 4 types:

1) Specialist terms that have their own definition: die Eucharistie (Eucharist), das Jesusgebet (Jesus Prayer), das Sacrament (holy mystery); narrow vocabulary is the most important and the most frequently used in professional texts and carries the greatest amount of information;

2) Interdisciplinary terms (including terms of related sciences): das Leben (life). In philosophy, it is a similar way of realizing existence on separate, every higher degrees of reality. In the scientific sense, life is associated with protoplasm as the highest known form of organization of matter. "From the theological point of view, the fragile 'miracle' of life is first and foremost a gift of God, as chance and creativity are explored in the animated being more clearly than in the inanimate world" ${ }^{\text {; }}$;

${ }^{22}$ Мовчун Є. С. Особливості перекладу українською мовою німецького комерційного Інтернет дискурсу : автореф. дис. на здобуття наук. ступеня канд. філ. наук : спец. 10.02.16 «Перекладознавство» / Є. С. Мовчун. - Київ, 2010. - С. 7.

${ }_{23}$ Міщенко А. Л. Лінгвістика фахових мов та сучасна модель науково-технічного перекладу : монографія / А. Л. Міщенко. - Вінниця : Нова Книга, 2013. - С. 16.

24 Короткий теологічний словник / Карл Рагнер, Герберт Форгрімлєр [перекл. О. Авраменко]. - Львів, 1996. - С. 179 - 180. 
3) Professionalisms, which may include nomenclature: der Rosenweihrauch (incense from rose), der Weihrauch "Ecclesia” (incense made from incense tree);

4) Professional jargon, which does not claim to be precise and unambiguous, it has a high level of imagery and emotionally colored meaning (has not been studied) ${ }^{25}$.

According to A.L. Mishchenko, the basis of a professional text is a terminological vocabulary, "which is the object of the study of terminology as a science of professional concepts and their nominations in professional languages. The main task of theoretical terminology is to create unified and standardized principles and methods of word formation, classification and systematization of branch terminological systems; normalization of the principles of systemic development of branch terminological systems, regulation of relations between concepts within terminological systems, which is the basis of applied terminological activity" ${ }^{26}$.

\section{Terms of the German Christian-theological terminology: Definition of the terms, characteristics}

Terminology is a "special vocabulary serving a particular field of science or technology" 27 . Terminology is used in the language in special subject fields; "this presupposes a division of language into as many speial sublanguages as there are separated subject fields or areas of knowledge and activity in a given linguistic community. From the point of view of terminology, therefore, the lexicon of a language consists of the many separate subsystems representing the knowledge structure of each subject field or discipline" ${ }^{28}$ :

- Bibelwissenschaft (Biblicla Studies): Neues Testamen (New Testament), Altes Testament (Old Testament), die Bibel (the Bible), die Synoptiker (synoptic Gospel);

- systematische Theologie (systematic theology): die Eklesiologie (ecclesiology), die Eschatologie (eschatology), die Trinität (Trinity).

\footnotetext{
${ }^{25}$ Кияк Т. Р. Теорія та практика перекладу (німецька мова) : [підручник для студентів вищих навчальних закладів] / Т. Р. Кияк, О. Д. Огуй, А. М. Науменко. - Вінниця : Нова книга, 2006. - С. 28-29.

26 Міщенко А. Л. Лінгвістика фахових мов та сучасна модель науково-технічного перекладу : монографія / А. Л. Міщенко. - Вінниця : Нова Книга, 2013. - С. 163.

${ }^{27}$ Кияк Т. Р. Лингвистические аспекты терминоведения : [учеб.пособие] / Т. Р. Кияк. К. : УМК ВО, 1989. - С. 7.

${ }^{28}$ Sage J.C. Practical Course in Terminology Processing. - Amsterdam, Philadelphia : John Benjamins Publishing Company, 1990. - P. 13. 
According to O.M. Tours terminological systems have some features. In particular, a terminological system is a set of terms that performs a communicative-thematic or communicative-situational task; elements of the structure are directly or indirectly related; there is no term that does not belong to any particular term system or to several at the same time, and they can overlap one another, forming a group of terms common to several terminological systems ${ }^{29}$. Thus, the terminological unit der Logos in the philosophical system of terms means "speech, intellect”. In the theological terminology it means "the word of God as an objectively manifested will of God and the power of creation of the universe" (Genesis 1: 3; Ps. 33: 6; Jn. 1, 1-3); "Jesus as the Incarnate Word and Divine Revelation” (Jn. 1:14; Rev. 19:13).

Terms as verbal designations of concepts that are included in the system of concepts of a particular area of professional knowledge, and as the basic units of language used for a specific purpose ${ }^{30}$. On the one hand they are important elements of the LSP used by professionals in various fields of science and technology for communication related to professional activity $^{31}$, and on the other hand, belong to a certain terminological system - a consciously constructed system of terms ${ }^{32}$. "Terms are the linguistic representation of concepts.”33. B.M. Golovin believes that the term is a single word or a noun phrase, which means a professional concept and is intended to meet the specific needs of communication in a particular profession ${ }^{34}$. V.A. Tatarinov describes the term as "a linguistic sign (word or phrase) that correlates with a specific concept, phenomenon or object" ${ }^{35}$. O. Selivanova defines the term as "a word or a compound that denotes the concept of a special sphere of communication in science, production, technology, art, in a particular field of knowledge or human activity" ${ }^{36}$. Y. A. Klimovytsky considers the term a word or a phrase,

${ }^{29}$ Тур О. М. Польова структура сучасної української терміносистеми землеустрою та кадастру / О. М. Тур // ЧДУ ім. П. Могили : наукові праці. - Т. 92. - № 79. - С. 69.

${ }^{30}$ Суперанская А. В. Общая терминология : вопросы теории / А. В. Суперанская, Н. В. Подольская, Н. В. Васильева. - [2-е изд. стер.]. - М. : Едиторал УРСС, 2004. - С. 14.

31 Жербило Т. В. Термины и понятия лингвистики : Общее языкознание. Социолингвистика : Словарь-справочник / Т. В. Жербило. - Назрань : Пилигрим, 2011. - С. 215.

32 Лейчик В. М. Терминоведение. Предмет, методы, стрктура : [4-е изд.] / В. М. Лейчик. - М. : Либроком, 2009. -С.107.

${ }^{33}$ Sage J.C. Practical Course in Terminology Processing. - Amsterdam, Philadelphia : John Benjamins Publishing Company, 1990. - P. 57.

${ }^{34}$ Головин Б. М. Термін і слово / Б. М. Головин. - Горький, 1980. - С. 276.

35 Татаринов В. А. Теория терминоведения / Татаринов В. А. - М. : Московский лицей, 1996 . - C. 157.

${ }^{36}$ Селіванова О. Сучасна лінгвістика : термінологічна енциклопедія / О. Селіванова Полтава : Довкілля-К, 2006. - С. 617. 
which is the unity of a sound sign and a corresponding concept in the system of concepts of a given field of science and technology ${ }^{37}$. O.S. Akhmanova calls the term a word or phrase of a special language, which is created to accurately express special concepts and name special objects $^{38}$. The term is a word or phrase that expresses a clearly defined concept of a particular field of science, technology, art, social and political life $^{39}$. The term is a linguistic unit (word or phrase) mostly of a substantive nature, which conventionally relates to the concept and object of the professional field and serves to concentrate, record, store and transmit professional information ${ }^{40}$.

"The term is a member of a particular terminological system, so terminology is not a random set of words, but a system of interrelated terms that denote the system of concepts of a particular branch of knowledge" ${ }^{41}$. Thus, the words die Offenbarung (revelation), die Schisma (schism), das Sacrament (sacrament) reflect the essence of certain theological concepts. The terms for each science are numbered and necessarily related to the concepts of a particular science. Therefore, the specificity of the term lies primarily in the clearly limited field of its use ${ }^{42}$.

The main task of the term is to nominate and optimize the process of professional communication. In this regard, the term should specifically reflect the results of both practical and research activities of the person, consolidate the knowledge acquired in the course of scientific and professional activity about the features of terminological objects, as well as identify their most important features ${ }^{43}$.

The nomination is closely related to such a thinking stage as concept formation. It involves the selection of that particular trait, feature or phenomenon of an object that would later serve as a name. The relationship between the term and the word is close. If a term called

\footnotetext{
${ }^{37}$ Климовицкий Я. А. Некоторые вопросы развития и методологи терминологических работ в СССР / Я. А. Климовицкий. - М. , 1967. - С. 34.

${ }^{38}$ Ахманова О. С. Словарь лингвистических терминов / О. С. Ахманова. - М. : Советская энциклопедия, 1969. - С. 474.

${ }^{39}$ Ганич Д.І. Словник лінгвістичних термінів / Д. І.Ганич, І. С. Олійник. - К. : ВШ, 1985. - С. 306.

40 Лемов А. В. Система, структура и функционирование научного термина / А. В. Лемов. - Саранск : изд-во Мордов. университета, 2000. - С. 77.

${ }^{41}$ Безгодова Н. Співвідношення понять термінологія - професіоналізм - номенклатура (теоретичний аспект) : [Електронний ресурс]. / Надія Безгодова // Вісник Львівського Університету. Серія Філологічна. - Вип. 34. - Ч. 1. - Львів, 2004. - С. 458 - 463. - Режим доступу : http://philology.lnu.edu.ua/v34_1.php.

${ }_{42}$ Реформатский А. А. Мысли о терминологии / А. А. Реформатский // Современные проблемы русской терминологии. - М., 1986. - С. 165-166.

${ }^{43}$ Володина М. Н. Научно-техническая терминология и общеупотребительная лексика : [Електронний ресурс]. - Режим доступу : http://library.krasu.ru/ft/ft/_ articles/0113883.pdf. 148
} 
a word belongs to the field of science or technology, then the word that denotes this term is a scientific and technical term ${ }^{44}$. The same can be said about the theological term: die Eucharistie (Eucharist), die Firmung (Confirmation), Apostolosche Väter (early fathers of the church), die Apokryphen (apocrypha) - the concepts called by these lexical units belong to the science of theology, they reflect the essence of the theological realities, and the words that denote them are Christiantheological terms.

The term as a unit of national language simultaneously belongs to a special linguistic subsystem and therefore serves as a special linguistic unit, which refers to special and professional concepts, which makes it possible to distinguish them among other units of the linguistic system ${ }^{45}$.

The terms are being examined in various terminological systems at the present stage of the development of linguistics. The term has a specific and defined scope and thus belongs to the vocabulary of a particular subtext that serves as a medium of communication in a particular professional field. The term is a part of a terminological system of a particular profession.

The term as "a word or verbal complex enters into systemic relations with other words and verbal complexes and forms with them in each specific case and at certain times a closed system, characterized by high informativeness, uniqueness, accuracy and expressive neutrality" 46 . According to V. Schmidt, the term should have such properties as: professional orientation, content, accuracy, uniqueness, brevity, as well as aesthetic, expressive and modal neutrality ${ }^{47}$. According to A.S. Dyakov, T.R. Kyyak and Z.B. Kudelko, the term is characterized by specific features, such as systematicity, definiteness (each term is compared with a clear, separate definition that focuses on the corresponding concept), brevity (this requirement is often contrary to the requirement of accuracy, i.e. completeness of the term), unambiguity, which should be sought within the same terminosphere, because at the level of several sublanguages the polysemy of the terms is a widespread phenomenon, expressive neutrality ${ }^{48}$. Taking into account the abovementioned, we can

\footnotetext{
${ }^{44}$ Квитко И. С. Термин в научном документе / И. С. Квитко. - Львов : Вища школа, 1976. - C. 9.

${ }^{45}$ Шмелёва О. Ю. Терминологические процессы в диахронии и синхронии (на материале английского языка) / О. Ю. Шмелёва. - С-Пб. : СПбГУЭФ, 2010. - С.10.

${ }^{46}$ Квитко И. С. Термин в научном документе / И. С. Квитко. - Львов : Вища школа, 1976. - C. 21.

${ }^{47}$ Schmidt S. J. Bedeutung und Begriff : Zur Fundierung einer sprachphilosophischen Semantik / S. J. Schmidt. - Braunschweig : Vieweg, 1969. - S. 12.

48 Д'яков А. С. Основи термінотворення: Семантичні та соціолінгвістичні аспекти / Д’яков А. С., Кияк Т. Р., Куделько З. Б. - К. : вид. дім “КМ Аcademia”, С. 13.
} 
conclude that systematicity, definiteness, uniqueness, brevity and accuracy are important properties of the term.

Considering the systematic nature of the term, it should be noted that it operates within a certain terminological system. A system (from gr. $\Sigma v \delta \tau \varepsilon \mu \alpha$ - a conjunction, a whole made up of parts) is a collection of elements that are in appropriate relations and bonds with each other and form a certain unity ${ }^{49}$. According to the dictionary of the Ukrainian language, organization and structure are also included into the system, which is the unity of regularly located and functional parts ${ }^{50}$. The basic element of the system is the structure, "the set of stable links of the object, ensuring its integrity and identity to itself that is, maintaining the main qualities in various external and internal changes". On this basis, the scientific term is a system in which three elements are structured, forming a lexical triangle:

1) the material shell of the word-term;

2) the actuality of objective reality related to it;

3) the concept of this reality ${ }^{51}$.

The term has a meaning in a particular term system because systematicity is one of its main characteristics. The systematicity of terminological unit is manifested, on the one hand, by the reflection of the notion expressed by the term, and on the other - by the motivational wordforming capabilities of the word-sign (term) ${ }^{52}$, for example, das Andreaskreuz (St. Andrew's Cross), das Petrus Kreuz (St. Peter's Cross). The systematicity of a particular term system, including the theological one, is also manifested in the availability of word-families in the terminology (term-families), which are "terms that are united on the basis of the common feature or pattern and have the same component" ${ }^{53}$. Wordfamilies in the terminology are the result of a morphological way of word formation in the terminology with the help of a root word, on the one hand. And on the other hand, of a syntactic way of their constructing, in the process of which the main component acquires the status of the definition, and vice versa, the significant component of the term is given the status

\footnotetext{
${ }^{49}$ Новая философская энциклопедия : [Електронний ресурс]. - Режим доступу : http://iph.ras.ru/elib/2736.html.

${ }^{50}$ Словник української мови : в 11 томах / АН УРСР. Інститут мовознавства / [ред. І. К. Білодід та ін.]. - Київ: Наукова думка, 1970 - 1980. - Т. 9. - С. 204.

51 Лемов А. В. Система, структура и функционирование научного термина / А. В. Лемов. - Саранск : изд-во Мордов. университета, 2000. - С. 8.

${ }^{52}$ Синьо В. В. Лінгвістичні особливості німецької фахової мови лісівництва : дис. канд. філ. наук : 10.02.04 / В. В. Синьо. - Ужгород, 2007. - С. 24.

${ }_{53}$ Бартков Б. И. Частность английских военных терминов и мощность их словообразовательных гнёзд / Б. И. Бартков // Особенности словообразования в системе и литературной норме. - Владивосток : ДВНЦ АН СССР, 1983. - С. 39.
} 
of the basic component of the derivative nomination ${ }^{54,55}$. The presence of the same determinant in a number of composites testifies to the common features in the respective concepts. For example, the term die Kirche (church) is a main component of such terminological units as: die Kirchenlehre (church teaching), der Kirchenvater (church father), die Kirchenstrafe (church punishment), das Kirchenjahr (church year), der Kirchenvorstand (church curatorium), die Kirchenprovinz (church province), etc.

When we refer to such a property of the term as definiteness, we understand that each term is related to a specific concept through definition ${ }^{56}$. The definition is an important condition for distinguishing it from a literary word, as well as for the creation, storage and transmission $\mathrm{f}$ scientific information ${ }^{57}$ :

Die Tugend ist eine beständige, feste Neigung, das Gute zu tun. Sie ermöglicht dem Menschen, nicht nur gute Taten zu vollbringen, sondern sein Bestes zu leisten. Mit all seinen sinnlichen und geistigen Kräften strebt der tugendhafte Mensch nach dem Guten. Er sucht es zu erreichen und entscheidet sich bei seinen konkreten Handlungen dafür ${ }^{58}$.

A virtue is an habitual and firm disposition to do the good. It allows the person not only to perform good acts, but to give the best of himself. The virtuous person tends toward the good with all his sensory and spiritual powers; he pursues the good and chooses it in concrete actions ${ }^{59}$.

For any term system uniqueness, or unambiguity, brevity, and accuracy are an ideal rather than a norm. While polysemy in the general vocabulary leads to the enrichment and expansion of the lexical composition, it is undesirable for the term system because it violates the language's attempt to maintain a clear correspondence between the referent and its nominative sign. In the terminology of many sciences it is much easier to find a polysemic term than an unambiguous one ${ }^{60}$. For example, the terminological unit die Gemeinde (community, parish) stands out as a polysemous one,

${ }^{54}$ Секунда Т. Принципи складання української технічної термінології / Т. Секунда // Вісник Ін-ту укр. наук. мови. - 1930. - Вип. 2. - С. 11-21.

${ }^{55}$ Казарина С. Г. Типологические характеристики отраслевых терминологий / С. Г. Казарина- Краснодар, 1998. - С. 154.

${ }_{56}$ Коваль А. П. Науковий стиль сучасної української літературної мови. Структура наукового тексту / А. П. Коваль. - К. : Видавництво Київського університету, 1970. - С. 262.

57 Лемов А. В. Система, структура и функционирование научного термина / А. В. Лемов. - Саранск : изд-во Мордов. университета, 2000. - С. 42.

${ }^{58}$ Katechismus der Katholischen Kirche : Neuübersetzung aufgrund der Editio typica latina. [2., veränd. Aufl.]. - München, Wien, Oldenbourg, Leipzig : St.-Benno-Verlag, 2003. - S. 476.

${ }^{59}$ Catechism of the Catholic Church : [Електронний ресурс]. - Режим доступу : http://www.vatican.va/archive/ENG0015/P64.HTM.

60 Лемов А. В. Система, структура и функционирование научного термина / А. В. Лемов. - Саранск : изд-во Мордов. университета, 2000.- С. 46. 
where the first meaning is an administrative unit (parish) in a church or religious congregation, and the second meaning is the gathering of all members of the parish for worship. The ambiguity of the term, namely the ability of the polysemous terms to belong to different paradigmatic series, leads to the emergence of synonymic, antonymic and homonymous relations, which are characteristic of the current terminological situation ${ }^{61}$. Ideally, the term should not have synonyms. However, in the term system under investigation the phenomenon of synonymy is present: die Fleischwerdung, die Menschenwerdung, die Incarnation - all these three terms mean incarnation.

Accuracy is the most appropriate correlation between linguistic expressions and objects, states or processes of the respective branches of human activity ${ }^{62}$. According to V. Sinyo, "the requirement of precision of a term means that it must contain essential features of the concept defined.

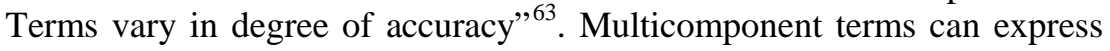
high precision of their concept: der Kreuzweg (the Stations of the Cross), die Glaubensspaltung (split of the church), das Glaubensbekenntnis (the creed, the symbol of faith). The short terms of the terminology we are exploring (partly from Latin and Greek) have a very high degree of accuracy, for example, der Exarch (Latin exarchus - Vorgesetzter < Gr. $\xi \alpha \rho \chi o \varsigma$ Anführer sein) (exarch), das Filioque (Lat. und vom Sohn) (Filioque), die Gnade (Old High German gnada - Wohlwollen, Gunst < Lat. gratia < Gr. Xópıs (mercy, mercy).

Along with the properties of the term having already been mentioned, the motivation of the terminological unit plays an important role. Although language is not exclusively composed of motivated lexical units, each linguistic system contains a reasonably high proportion of motivated potential. The language system as a whole is aimed at increasing the capacity of motivation in such a way as to restore or re-create the connection of motivation. In response to the constant phonological and semantic changes that destroy the link of motivation, compensatory changes are coming to the fore. They link the formal and the internal form of language more closely, rationally forming the link between form and meaning ${ }^{64}$. F. de Saussure believes that motivation is more complete,

61 Закреницька Л. А. Англійська християнсько-богословська терміносистема : генезис, структура, семантика : дис. канд. філ. наук : 10.02.04 / Л. А. Закреницька. - Хмельницький, 2011. - C. 29.

${ }^{62}$ Roelcke T. Fachsprachen / T. Roelcke - Berlin: Erich Schmidt Verlag, 2005. - S. 61.

${ }^{63}$ Синьо В. В. Лінгвістичні особливості німецької фахової мови лісівництва : дис. канд. філ. наук : 10.02.04 / В. В. Синьо. - Ужгород, 2007. - С. 26.

${ }^{64}$ Wurzel W. U. Zur Dialektik im Sprachsystem : Widerspruch - Motiviertheit Sprachveränderung / W. U. Wurzel // Deutsch als Fremdsprache. - 1984. - S. 208. 
the easier it is to decompose it into parts from which one can understand the meaning of the whole ${ }^{65}$.

Considering the problem of motivation at the level of the term system, it should be noted that terms based on word-forming resources of both the native language and formed on the basis of borrowed term elements can be motivated. However, they are motivated in different ways. In one case it is often a question of metaphor or metonymy, in another it is a term motivated by a corresponding set of term elements ${ }^{66}$. Motivation is the mediator between the form and the content of the sign. The name, or rather its internal form, which is interpreted as the "basis of motivation" is a means of motivation process ${ }^{67}$. This is the internal form of the word "that induces articulate sound to express the thought taken in the totality of its connections and systematicity" ${ }^{\text {68 }}$. It does not come down only to the etymology of the word, or to the lexical meaning, to the motivation, or to the simple sum of the meanings of the constituent morphemes. $<\ldots>$ The internal form is a mental interiorized image, potentially abstracting and displaying, in the form of an apperception, one or more essential features of denotation, evoked and fixed in the memory of the native speaker by the morphemic structure of the word or expression" ${ }^{\text {"69 }}$.

V. Fleischer and S. Ulmann distinguish three types of motivation: phonetic-phonemic, morphological-semantic and figurative ${ }^{70}$, ${ }^{71}$. A.S. Dyakov, T.R. Kyyak and Z.B. Kudelko suggest a somewhat different division and distinguish between three types of motivation, such as: sign (semiotic), formal (word-forming) and content (intense). The very fact of existence and use of the word points to the sign motivation, since there are no totally unmotivated lexical units in the language. All of them are in some way interrelated with the corresponding meaning, at least at the level of the common vocabulary. Formal motivation includes external form motivation and internal form motivation (morphological and semantic) ${ }^{72}$.

${ }^{65}$ Соссюр де Ф. Курс общей лингвистики / Ф. де Соссюр. - Екатеринбург : изд-во Урал. ун-та, 1999. - С. 157.

${ }_{66}^{66}$ Суперанская А. В. Общая терминология : вопросы теории / А. В. Суперанская, Н. В. Подольская, Н. В. Васильева. - [2-е изд. стер.]. - М. : Едиторал УРСС, 2004. - С. 107

${ }^{67}$ Прядохин М. Г. Пособие по изучению нового китайского фонетического алфавита : текст / М. Г. Прядохин. - М. : Восточная литература, 1960. - 9 с.

${ }^{68}$ Потебня А. А. Из записок по русской грамматике. Об изменении значения и заменах существительного / А. А. Потебня. - М. : Просвещение, 1968. - Т. 3. - С. 116.

69 Д'яков А. С. Основи термінотворення: Семантичні та соціолінгвістичні аспекти / Д'яков А. С., Кияк Т. Р., Куделько 3. Б. - К. : вид. дім “КМ Аcademia”, 2000 - С. 73 - 74.

${ }^{70}$ Fleischer B. Wortbildung der deutschen Gegenwartssprache / B. Fleischer, H. Bartz. Tübingen, 1992. - S. 14.

${ }^{71}$ Ullmann S. The principles of Semantics / S. Ullmann. - Glasgow, 1963. - P. 52.

72 Д'яков А. С. Основи термінотворення: Семантичні та соціолінгвістичні аспекти / Д'яков А. С., Кияк Т. Р., Куделько 3. Б. - К. : вид. дім “КМ Academia”, 2000 - С. 81. 
Morphological-semantic motivation by internal form encompasses the relation between words at the morphological and semantic levels. According to E.S. Kubriakova, "the key to the semantic reading and interpretation of any word is, after all, its superficial morphological structure" ${ }^{\text {,3 }}$. Morphological motivation is first and foremost defined by a word-forming model of the lexical unit, such as the suffix -ung: die Bekehrung (conversion). Semantic motivation is the result of the relationship between word-forming formants and the word stem, between the new and the previous meaning: die Heiligsprechung (proclamation of the saints) ${ }^{74}$.

Intense motivation is a "structural-semantic characteristic of a lexical unit explaining a rational lexical-semantic link between the meaning and the internal form of the given unit by means of language,"75. It acts as a link between the form and the semantic content of the language sign; it is determined by the ability of the internal form to display the most relevant features of the linguistic content of a word or expression, establishes its structural and semantic features in comparison with lexical meaning. ${ }^{76}$ Content motivation is clearly evident, first of all, in Christian theological terms-composites in the German language.

Internal form and motivation may contain different amount of information. Accordingly, we distinguish:

1) the full motivation of the inner form (when the form reflects a feature that is completely included in the meaning): der Kelchtuch ein Leientüchlein zum Austrocknen des Meßkelches (lention);

2) partial motivation (when there is a part of the linguistic content of the unit which is common to the internal form and lexical meaning) : Christi Himmelfahrt - Aufnahme Christi in den Himmel (Ascension);

3) absence of motivation (no morpheme included in the internal form has a corresponding meaning): das Pontifikalamt - von einem Bischof gehaltene feierliche Messe (festive Worship);

4) absolute motivation (complete coincidence of semantic features of internal form and lexical meaning): die Fastenpredigt - Predigt in der Fastenzeit (sermon at the time of fasting) ${ }^{77}$.

${ }^{73}$ Кубрякова Е. С. Типы языковых значений : Семантика производного слова / Е. С. Кубрякова. - М. : Наука, 1981. - С. 19.

74 Д'яков А. С. Основи термінотворення: Семантичні та соціолінгвістичні аспекти / Д’яков А. С., Кияк Т. Р., Куделько З. Б. - К. : вид. дім “КМ Асаdemia”, 2000 - С. 81.

${ }^{75}$ Кияк Т. Р. Лингвистические аспекты терминоведения : [учеб.пособие] / Т. Р. Кияк. К. : УМК ВО, 1989. - С. 38.

76 Д'яков А. С. Основи термінотворення: Семантичні та соціолінгвістичні аспекти / Д’яков А. С., Кияк Т. Р., Куделько З. Б. - К. : вид. дім “КМ Асаdemia”, 2000 - С. 83.

${ }_{77}^{7 и я к ~ Т . ~ Р . ~ Л и н г в и с т и ч е с к и е ~ а с п е к т ы ~ т е р м и н о в е д е н и я ~: ~[у ч е б . п о с о б и е] ~ / ~ Т . ~ Р . ~ К и я к . ~-~}$ К. : УМК ВО, 1989. - С. 39. 
Full motivation can be considered the most appropriate, since form and meaning are mutually consistent in it, which promotes, as a rule, better mutual understanding. Thus, motivation is a significant feature of the term. It is characteristic primarily for derivative terms and composite terms. It serves as a connecting element between the form and the content of the sign. There are two divisions of motivation. One division characterizes the amount of information contained in the internal form of the sign, and, accordingly, we can distinguish between full, partial, absolute motivation and its absence. Another considers sign, formal and content motivation.

\section{CONCLUSIONS}

Summarizing the previously mentioned, we can conclude that the professional language of theology is the totality of all linguistic means used in the theological field of communication to ensure understanding between people in this field. The theological language of theology, which exists at the level of vocabulary, syntax and text, includes theological terms. Theological terms form the terminological system of theology that serves theology as a field of science.

Basing on the results of our research, we can claim that German Christian-theological terms are systemic, definable, and partly characterized by unambiguity, accuracy and brevity. The systematicity of the studied terminological system is based on the word-family in the German terminology of theology. The presence of the same determinant in a number of composites indicates common ground in the relevant concepts. The terms of Christian-theological terminological system relate to specific concepts through definitions. Partial uniqueness of German Christian-theological terms is conditioned by the presence of polysemy and synonymy available in the studied term system. Motivation is an important feature of the term, clearly traced to derivative terms and composite terms, and serves as a connecting element between the form and meaning of the sign.

\section{SUMMARY}

In the following research, the author gives a general overview of the theological terminology in German. The connection between Languages for Special Purposes and terminology is settled. The horizontal and vertical structuring of the Languages for Special Purposes and the place of theology as science are presented there. Aspects of motivation have been analysed. For the first time, the German terms of professional theological language at the level of vocabulary have been analysed. The terms of German Christian theological terminology according to the motivation aspect and the aspect of definitiveness have been studied. 


\section{REFERENCES}

1. Ахманова О. С. Словарь лингвистических терминов / О. С. Ахманова. - М. : Советская энциклопедия, 1969. - 608 с.

2. Бартков Б. И. Частность английских военных терминов и мощность их словообразовательных гнёзд / Б. И. Бартков // Особенности словообразования в системе и литературной норме. Владивосток : ДВНЦ АН СССР, 1983. - С. 38-48.

3. Безгодова Н. Співвідношення понять термінологія - професіоналізм - номенклатура (теоретичний аспект) : [Електронний ресурс]. / Надія Безгодова // Вісник Львівського Університету. Серія Філологічна. - Вип. 34. - Ч. 1. - Львів, 2004. - с. 458 - 463. - Режим доступу : http://philology.lnu.edu.ua/v34_1.php.

4. Володина М. Н. Научно-техническая терминология и общеупотребительная лексика : [Електронний ресурс]. - Режим доступу : http://library.krasu.ru/ft/ft/_ articles/0113883.pdf.

5. Ганич Д.І. Словник лінгвістичних термінів / Д. І. Ганич, I. С. Олійник. - К. : ВШ, 1985. - 360 с.

6. Головин Б. М. Термін і слово / Б. М. Головин. - Горький, 1980. - $156 \mathrm{c}$.

7. Греческо-русский словарь / [под ред. А.Д. Вейсмана]. С. Петербург, 1899. - 1368 с.

8. Д'яков А. С. Основи термінотворення: Семантичні та соціолінгвістичні аспекти / Д'яков А. С., Кияк Т. Р., Куделько 3. Б. К. : Вид. дім «КМ Аcademia», $2000-218$ с.

9. Жербило Т. В. Термины и понятия лингвистики : Общее языкознание. Социолингвистика : Словарь-справочник / Т. В. Жербило. - Назрань : Пилигрим, 2011. - 280 с.

10.Закреницька Л. А. Англійська християнсько-богословська терміносистема : генезис, структура, семантика : дис. канд. філ. наук : 10.02.04 / Л. А. Закреницька. - Хмельницький, 2011. - 243 с.

11.Казарина С. Г. Типологические характеристики отраслевых терминологий / С. Г. Казарина- Краснодар, 1998. - 276 с.

12.Катехизм Української Греко-Католицької Церкви : Христос наша Пасха. - Львів : Свічадо, 2011. - 336 с.

13. Католическая Энциклопедия в 5-ти томах. - М. : Издательство Францисканцев, 2002. - Т. 1. - 1906 с.

14.Квитко И. С. Термин в научном документе / И. С. Квитко. Львов : Вища школа, 1976. - 128 с.

15.Кияк Т. Р. Лингвистические аспекты терминоведения : [учеб.пособие] / Т. Р. Кияк. - К. : УМК ВО, 1989. - 104 с. 
16.Кияк Т. Р. Теорія та практика перекладу (німецька мова) : [підручник для студентів вищих навчальних закладів] / Т. Р. Кияк, О. Д. Огуй, А. М. Науменко. - Вінниця : Нова книга, 2006. - 592 с.

17.Кияк Т. Р. Перекладознавство (німецько-український напрям) : [підруч. для студ. вищ. навч. закл.] / Т. Р. Кияк, А. М. Науменко, О. Д. Огуй. - К. : Київський нац. університет, 2009. - 544 с.

18. Климовицкий Я. А. Некоторые вопросы развития и методологии терминологических работ в СССР / Я. А. Климовицкий. М., 1967. - C. 34.

19. Коваль А. П. Науковий стиль сучасної української літературної мови. Структура наукового тексту / А. П. Коваль. - К. : Видавництво Київського університету, 1970. - 306 с.

20.Короткий теологічний словник / Карл Рагнер, Герберт Форгрімлєр [перекл. О. Авраменко]. - Львів, 1996. - 663 с.

21.Кубрякова Е. С. Типы языковых значений : Семантика производного слова / Е. С. Кубрякова. - М. : Наука , 1981. - 200 с.

22. Лейчик В. М. Терминоведение. Предмет, методы, стрктура : [4-е изд.] / В. М. Лейчик. - М. : Либроком, 2009. - 256 с.

23. Лемов А. В. Система, структура и функционирование научного термина / А. В. Лемов. - Саранск : изд-во Мордов. университета, 2000. - $192 \mathrm{c}$.

24. Міщенко А. Л. Лінгвістика фахових мов та сучасна модель науково-технічного перекладу : монографія / А. Л. Міщенко. Вінниця : Нова Книга, 2013. - 448 с.

25. Мовчун С. С. Особливості перекладу українською мовою німецького комерційного Інтернет дискурсу : автореф. дис. на здобуття наук. ступеня канд. філ. наук : спец. 10.02.16 «Перекладознавство» / Є. С. Мовчун. - Київ, 2010. - 21 с.

26.Новая философская энциклопедия : [Електронний ресурс]. Режим доступу : http://iph.ras.ru/elib/2736.html.

27. Обер о. Ж.-М. Моральне богослов'я / о. Жан-Марі Обер : [переклад з італ. о. д-ра М. І. Любачівського] : [2-ге вид, виправ.]. Львів : Стрім, 1997. - 287 с.

28.Потебня А. А. Из записок по русской грамматике. Об изменении значения и заменах существительного / А. А. Потебня. М. : Просвещение, 1968. - Т. 3. - 551 с.

29.Прядохин М. Г. Пособие по изучению нового китайского фонетического алфавита : текст / М. Г. Прядохин. - М. : Восточная литература, 1960. - 21 с. 
30.Реформатский А. А. Мысли о терминологии / А. А. Реформатский // Современные проблемы русской терминологии. - М., 1986. С. $163-198$.

31.Секунда Т. Принципи складання української технічної термінології / Т. Секунда // Вісник Ін-ту укр. наук. мови. - 1930. Вип. 2. - С. 11-21.

32. Селіванова О. Сучасна лінгвістика : термінологічна енциклопедія / О. Селіванова - Полтава : Довкілля-К, 2006. - 716 с.

33. Синьо В. В. Лінгвістичні особливості німецької фахової мови лісівництва : дис. канд. філ. наук : 10.02.04 / В. В. Синьо. - Ужгород, 2007. -223 c.

34. Словник української мови : в 11 томах / АН УРСР. Інститут мовознавства / [ред. І. К. Білодід та ін.]. - Київ: Наукова думка, 1970 1980. - Т. 9. -915 c.

35. Соссюр де Ф. Курс общей лингвистики / Ф. де Соссюр. Екатеринбург : изд-во Урал. ун-та, 1999. - 432 с.

36. Стасяк С.-Я. Основи догматичного богослов'я / о. С.-Я. Стасяк, о. Р. Завіла. - Львів : Місіонер, 1997. - 310 с.

37. Суперанская А. В. Общая терминология : вопросы теории / А. В. Суперанская, Н. В. Подольская, Н. В. Васильева. - [2-е изд. стер.]. - М. : Едиторал УРСС, 2004. - 248 с.

38. Татаринов В. А. Теория терминоведения / Татаринов В. А. М. : Московский лицей, 1996 . - 311 с.

39. Термінологічно-правописний порадник для богословів та редакторів богословських текстів. - Львів, вид. Інституту богословської термінології та перекладів Українського Католицького Університету, 2005. - 130 с.

40.Тур О. М. Польова структура сучасної української терміносистеми землеустрою та кадастру / О. М. Тур // ЧДУ ім. П. Могили : наукові праці. - Т. 92. - № 79. - С. 68-72.

41.Шмелёва О. Ю. Терминологические процессы в диахронии и синхронии (на материале английского языка) / О. Ю. Шмелёва. С-Пб. : СПбГУЭФ, 2010. - 120 с.

42. Catechism of the Catholic Church : [Електронний ресурс]. - Режим доступу : http://www.vatican.va/archive/ENG0015/_P17.HTM\#7X.

43.Duden, Etymologie : Herkunftswörterbuch der deutschen Sprache / [bearb. von G. Drosdowski]. - Mannheim, Leipzig, Wien, Zürich : Dudenverlag, 1997. - 839 S.

44. Fleischer B. Wortbildung der deutschen Gegenwartssprache / B. Fleischer, H. Bartz. - Tübingen, 1992. - 375 S. 
45. Hoffmann L. Kohärenz und Kohäsion in wissenschaftssprachlichen Texten: ein Analysebeispiel // Fachsprachen. Ein internationales Handbuch zur Fachsprachenforschung und Terminologiewissenschaft. - Berlin New York, 1998. - S. 610-617.

46. Hoffmann L. Kommunikationsmittel Fachsprache / L. Hoffmann // Forum für Fachsprachen-Forschung. - [2., völlig neu bearb.]. - Tübingen : Narr, 1985. - B. 1 - 307 S.

47.Katechismus der Katholischen Kirche : Neuübersetzung aufgrund der Editio typica latina. - [2., veränd. Aufl.]. - München, Wien, Oldenbourg, Leipzig : St.-Benno-Verlag, 2003. - 824 S.

48. Möhn D. Fachsprachen. Eine Einführung / D. Möhn, R. Pelka. Tübingen, Max Niemeyer Verlag, 1984. - $171 \mathrm{~S}$.

49. Roelcke T. Fachsprachen / T. Roelcke - Berlin: Erich Schmidt Verlag, 2005. - 253 S.

50. Sage J.C. Practical Course in Terminology Processing. - Amsterdam, Philadelphia : John Benjamins Publishing Company, 1990. - 264 p.

51.Schmidt S. J. Bedeutung und Begriff : Zur Fundierung einer sprachphilosophischen Semantik / S. J. Schmidt. - Braunschweig : Vieweg, 1969. - $176 \mathrm{~S}$.

52.St. Thomas Aquinas : [Електронний ресурс]. - Режим доступу : https://dhspriory.org/thomas/summa/FP/FP001.html\#FPQ1OUTP1

53. Ullmann S. The principles of Semantics / S. Ullmann. - Glasgow, 1963. $-352 \mathrm{p}$.

54. Wurzel W. U. Zur Dialektik im Sprachsystem : Widerspruch Motiviertheit - Sprachveränderung / W. U. Wurzel // Deutsch als Fremdsprache. - 1984. - S. $201-211$.

Information about the author: Veresh M. T.,

Candidate of Philological Sciences, Associate Professor at the Faculty of Foreign Philology, Department of German Philology,

Uzhhorod National University 3, Narodna Sq., Uzhhorod, 88000, Ukraine 